\title{
Loving Criticism: A Spiritual Philosophy of Social Change
}

\section{Sharon Doetsch-Kidder}

This essay Meditates on the SPIRITUAL challenges of doing activist and political work. Critics and activists have long appreciated the necessary focus on the material dimensions of social change encouraged by antiracist feminists such as Audre Lorde, Gloria Anzaldúa, and bell hooks, but we frequently forget to attend to the spiritual aspects of liberation articulated by these same authors. How we do our work matters, whether as scholars or as activists. Paying attention to the spirit of our work can help us to produce knowledge that is useful to those struggling to survive, that serves humanity, and that brings more love, peace, and compassion to the world. We can draw on ancient and internal knowledges to help us find alternatives to the oppositional thinking that is the root of violence and to treat with understanding and kindness those with whom we disagree, thereby opening up worlds of possibility for creating deep, lasting change.

Already I have trouble with language. The material and spiritual are not in opposition. Our spiritual interconnection is part of our global material interdependence; indeed this notion is central to what historian Becky Thompson names multiracial feminism"the liberation movement spearheaded by women of color in the United States in the 1970s that was characterized by its international perspective, its attention to interlocking oppressions, and its support 
of coalition politics." ${ }^{1}$ Also, activists and intellectuals are not distinct groups. Many whom I cite in this essay are writer-activists. The nature of much activist work is critique of the status quo, and the work of socially engaged criticism is activist in nature, so these terms are largely interchangeable. Most of the thinkers on whom I draw here write for people engaged in all aspects of social change work - political, cultural, spiritual, intellectual-categories that also overlap and dissolve into one another; my usage only indicates whether an author's primary work is scholarly writing or political organizing. I write of "activists" and "intellectuals" or "critics," but mostly of "we" who are engaged in the work of positive social change. Those of us familiar with histories of exclusion are trained to question any use of "we," using specificity to indicate that we understand we cannot speak for everyone. I insist on using a hopeful "we" to reflect my very broad view of what constitutes social change work. Teaching, parenting, writing, performing, creating art, building communities, acting ethically and responsibly - all of these acts, as well as explicitly political activism and organizing, work to make the world a better place if they are done with "the spirit of love and protection for all things." ${ }^{2}$

\section{BACKGROUND}

Antiracist feminist activists and intellectuals such as Anzaldúa, Lorde, hooks, Alice Walker, Akasha Gloria Hull, Cherríe Moraga, Chela Sandoval, Paula Gunn Allen, Mab Segrest, M. Jacqui Alexander, Leela Fernandes, and AnaLouise Keating have been important voices in incorporating spirit into social change work. They have been paying attention to not just when and where but how we enter into discourse and social interaction, so that our work reflects our best values rather than the negative emotions often generated in response to conflict. ${ }^{3}$ Scholars and practitioners of feminist spirituality, such as Luisah Teish, Starhawk, Charlene Spretnak, Carol Christ, Katie Cannon, Mary E. Hunt, Judith Plaskow, Delores Williams, Rita Gross, and Ada María Isasi-Díaz, have been integrating spiritual and political work for decades. ${ }^{4}$ Their work continues legacies of spiritual social change that can be traced through civil rights movements, Black women's clubs, and women's suffrage and abolitionist struggles in the United States, as well as decolonization and other liberation movements 
around the world. ${ }^{5}$ Spiritual social change work consistently links spirituality with political practice, theorizing and demonstrating the importance of spirituality for the vitality of feminism and progressive social movements. Yet such attention to spirituality remains marginal within women's and queer studies and progressive social movements. Here I reflect on the implications of spirit for how we work toward social change.

In examples of how intellectuals and activists attend to spirit, I find lessons that can guide us - activists and scholars - toward what I call "loving criticism." ${ }^{6}$ Criticism, of course, can be loving in countless ways. Rather than attempting to describe loving criticism in limiting and exclusionary ways, I meditate here on five aspects of loving criticism that I have found in my research: loving criticism honors our roots, accepts our shared humanity, accepts our power to change our lives and the world, faces conflict with kindness, and nourishes us through positive action. These aspects may blur into each other, but each represents a form of engagement that I find helpful. The loving criticism that has been most inspiring to me seeks understanding of others on their own terms, along with understanding larger structures that work on and through individual lives.

I build on the work of multiracial feminism and feminist spiritualities as well as a legacy of criticism and creative production that views the behavior of individuals and groups with respect and interprets cultural texts and artifacts with a sense of human dignity. I have integrated into this discussion of loving criticism data from my study of intersectional activists whose everyday theorizing confirms the insights of multiracial feminist writers. My study, carried out in 2004-5, sought "activists who identify as queer and feminist and/or as transgender who are engaged in antiracist, global and economic justice, trans and intersex rights, or disability rights work in the DC area." I recorded four to seven hours of oral history with each participant. ${ }^{7}$ The group includes five Asian-Pacific Islanders, five Black people, five Latinas, two Native Americans, two multiracial people, and six White people. They are eighteen women, three men, and four trans people, ranging in age from twenty-five to fifty-six. Each of these "intersectional activists" addressed more than one structure of oppression or form of discrimination (racism, classism, sexism, heterosexism, transphobia, ableism, nationalism, etc.), and I hoped 
to discover how such people came to understand and enact intersectionality on the ground. ${ }^{8}$ Many of my participants were committed both to working with people in local communities as well as with the government structures that affect them, as is typical of DC-area activists. But instead of political analysis, the activists in my study described their reasoning and motivations largely using the language of caring about themselves and others, and they spoke of their beliefs and principles and of the satisfaction found in social change work. Working inductively from the interview data, I found in their narratives evidence of a common spirit that echoes a consciousness found in much antiracist feminist writing. The convergence between interview data and published theory led me to focus on the philosophy they share, one that I call "loving criticism." The framework of "loving criticism" represents my attempt to explain how spirit manifests in activist and critical practice. I draw on these oral histories, along with other narratives of intersectional activism and feminist, queer, and Buddhist thinking, to describe this common philosophy of social change.

The emphasis on spirituality in this essay reflects its important place in US-based antiracist feminist queer struggles for justice. In addition to drawing on Christianity and indigenous spiritualities of Africa and the Americas, feminists such as Walker, hooks, Segrest, and Eve Kosofsky Sedgwick have explicitly discussed Buddhism, citing Buddhist teachers such as Thich Nhat Hanh. ${ }^{9}$ I use work by Thich Nhat Hanh and other Buddhist teachers here to explain the spiritual significance of intersectionality and loving criticism. While the themes discussed here are present in many religious traditions, I find Buddhist philosophy, which is based on practices of observing the mind, particularly useful as a way to discuss spirituality without relying on a god(dess), while leaving space for those who believe in the Divine to interpret our oneness as oneness with God(dess). The result of this combination of feminist and queer theory and Buddhist philosophy is a view of a particular form of consciousness that can be found across theoretical and disciplinary divisions.

In describing loving criticism, I identify principles guiding the practice of differential consciousness, one of five forms of oppositional consciousness that Sandoval maps in Methodology of the Oppressed. ${ }^{10}$ The first four forms of oppositional consciousness identified by 
Sandoval represent ideological stands but the fifth form, differential consciousness, enables movement between and among these other four positions. "Like the clutch of an automobile," the differential enables an activist or group to analyze a problem or situation and choose an appropriate tactic. Differential consciousness lifts the other forms of oppositional consciousness out of dogmatic practice and transforms those forms into "tactical weaponry for intervening in shifting currents of power." 11 Sandoval's tremendous contribution is in articulating a form of consciousness that is a tactical and yet ethical practice of "opposition to oppressive authorities," geared toward survival and guided by love. ${ }^{12}$ Here, I revisit the roots of differential consciousness in intuition, feeling, and spiritual knowledge and describe principles - which are spiritual as well as ethicalthat can guide its praxis. ${ }^{13}$

While most progressive studies of social problems come from a place of love, what I think of as loving criticism chooses love and healing as objects of study. Spiritual activist Marianne Williamson describes the importance of love for social change: "We don't need deeper analysis of our sicknesses so much as we desperately need a more passionate embrace of the only thing that heals them all." ${ }^{14}$ Sedgwick notes that the focus on "unveiling" the hidden workings of power - what she terms "paranoid" reading — has become a dominant critical approach in cultural studies. She seeks other forms of criticism that can coexist with a serious and complex understanding of oppression. While the paranoid position seeks to expose violence and exercises of oppressive power in order to never be surprised by bad news, what she terms the "reparative" approach — what I call loving criticism - "is additive and accretive. Its fear, a realistic one, is that the culture surrounding it is inadequate or inimical to its nurture." ${ }^{15}$ These are not opposing critical practices but have different feelings and different effects. Because the culture of criticism is so distrustful of love, faith, and joy, we need to work to sustain ourselves, and loving criticism is part of that self-nourishing work.

As scholarship on US-based feminist spiritualities shows, countless feminist activists, in communities large and small in a range of contexts, have worked to live by some or all of the principles I connect with spirit in this essay. Feminists and other progressive activists have experimented with organizational structures and 
individual and collective practices that seek to interrupt binary thinking, focus on connections, and bring both more justice and more kindness to the world. Some called their approach "sisterhood," others "friendship," terms that have carried different meanings and practices in various contexts. ${ }^{16}$ Given the many challenges presented by social structures and practices that encourage divisiveness, it is rare to find individuals or groups that maintain a spiritual approach consistently. Many have reflected on their failures, and feminists have discussed at length the virtues of various models of collectivity, working to find an approach that can bridge our many differences. $^{17}$

In the first decade of the twenty-first century, feminists write more and more of the visions that can sustain activism and lead us to a more just world, producing anthologies such as Anzaldúa and Keating's This Bridge We Call Home: Radical Visions for Transformation and Alexander, Lisa Albrecht, Sharon Day, and Segrest's Sing, Whisper, Shout, Pray! Feminist Visions for a Just World. ${ }^{18}$ Inspired by such work, I combine aspects of philosophies described by activists I interviewed and by activistwriters into a kind of composite, which I consider to be a spiritual or loving approach to social criticism. I find it heartening to see how people keep trying to connect, to heal the splits within and among ourselves, and to create communities stronger than the ones we inherited, as well as to see how people find meaning in these efforts. Here I meditate on aspiration, intention, and methods, because reflecting on these intentions in relation to our methods can help us figure out how to enact loving criticism more often, in more ways, and in more areas of our lives.

\section{Honor Our Roots}

Preserving histories and expressing gratitude for the work of those who have come before, loving criticism restores value to old ways and knowledges that can support people struggling to survive and/ or working for progressive change. Like Lorde and Anzaldúa, hooks writes of the importance of recovering old knowledges and practices that counter the psychic effects of oppression: "We come from a long line of ancestors who knew how to heal the wounded black psyche when it was assaulted by white-supremacist beliefs." Although the transmission of these "useful" knowledges has been broken, hooks 
affirms our ability to access old ways of thinking for use in our lives. ${ }^{19}$ Traces of past wisdom exist deep in our bodyminds - a term used by philosopher David E. Shaner to refer to "the presence of both [mind- and body-] aspects in all experience." ${ }^{20}$ This deep wisdom can be accessed through intuition, attention to feeling, and spiritual practices. Lorde's notion of the erotic describes how feeling lets us know when we have accessed some older knowledge or deeper truth whose direct transmission may have been broken. The erotic is a powerful feeling of truth discovered and lived, a sense of satisfaction when our actions are in harmony with the universe and express our deepest selves, a feeling of joy when we feel connected with the world around us. ${ }^{21}$ Paying attention to these feelings within ourselves as well as continually asking ourselves how our work serves the purpose of bringing love and social justice into the world leads to loving criticism, through which we can honor our past and change our "habits of thinking and being." 22

Many activists work to understand their connections with the past and appreciate how they have come to be where they are in life. Biracial lesbian feminist activist Lisa Weiner-Mahfuz speaks of her ancestors when describing her understanding of her purpose, which is to build bridges between different groups. She says of her struggles with being different, "I do feel very strongly that I would not have been given this, the physical disability, the learning disability, being Jewish and Arab, being a lesbian, and dealing with that whole coming out and sexuality stuff. That is a gift, I think, for me, and I know that I am supposed to do something with that, not to further myself, but to be a bridge." Viewing herself in connection with others who have come before her, Lisa is grateful for the challenges she faces. ${ }^{23}$ Gratitude transforms her painful experiences of difference and marginalization into gifts that enable her to work across differences. As a lesbian-rights field organizer and "bridge builder" who operates a consulting firm for nonprofit organizations, she uses her experience to connect with those who have come before her and to help people who are different better understand each other and work together.

In activism, organizers may honor their roots by remembering and thanking those whose work has inspired or enabled theirs. Activists in my study primarily described private practices, such as 
maintaining altars, meditation, and verbal or visual expressions, through which they express gratitude for predecessors and resources that support them. Other organizers may incorporate gratitude into public demonstrations such as the "Sistahs Steppin' in Pride" festival and dyke march in Oakland, California. Antiracist feminist scholar Elizabeth Currans, who studied this 2004 event, explains that its main purpose is to celebrate and build community by connecting the participants to a history of queer women of color and to each other. Through a ritual thanking of ancestors and carrying signs memorializing women from the East Bay, organizers and participants connect themselves with those who have gone before them and with the earth that sustains all life, as well as with each other. ${ }^{24}$ Sistahs Steppin' makes explicit the spiritual dimensions of intersectional activism. The act of giving thanks to ancestors is an act of healing and building and sustaining community as well as a political celebration of individuals whose lives have been devalued.

Being grateful for those whose work has come before ours and for all that sustains us is important spiritual and emotional work. The 17th Karmapa, a Buddhist teacher, explains the power of gratitude: if you appreciate "how other sentient beings have been kind to you, ... your happiness will increase and your altruistic heart will become stronger." Because we are all interdependent, "everyone is kind to us." ${ }^{25}$ In contemporary times, we are dependent on a larger-than-ever network of people for food, clothing, care, and shelter. Without their kindness, our lives would be much more difficult. Giving thanks to those whose lives and work support our own, we feel more satisfaction and a greater desire to help others.

Gratitude is also important for anti-oppression research and teaching. Antiracist feminist scholar Cynthia Dillard defines gratitude as "the acknowledgement of service to 'something bigger' that guides the very purposes of our research." Research done with the spirit of gratitude for all those who have worked toward the purpose of restoring dignity to those who have suffered discrimination and violence is healing work that enables scholars "to more clearly recognize humans in our various ways of being." Recognition of those who have come before us and of the energy that moves through us, which some think of as divine spirit, enables a clearer understanding of ourselves, which enables a clearer understanding of humanity. 
This understanding, according to Dillard, enables "more principled relationships" and works toward the "collective survival" of "the African family" and, I would add, all humans. ${ }^{26}$ By acknowledging the work that makes ours possible and finding the best in work that has come before ours, critics and activists honor our roots and encourage the joy, faith, and loving action that flow from gratitude.

\section{Accept Our Shared Humanity}

Lorde, Anzaldúa, and other multiracial feminists have, throughout their work, emphasized the importance of working for social change while keeping our shared humanity in mind. Their critiques of difference, which have shaped understandings of race, class, gender, and sexuality since the 1970s and 1980s, have gone hand in hand with recognition of sameness and calls for deconstructing our internal borders. Keating fears that the term "sameness" implies that we are identical and prefers the term "commonality." ${ }^{27}$ But by "sameness," I mean that we share more than the qualities that we have in common as humans. The energy that runs through each personour "ki" or "qi," in Japanese or Chinese philosophy, respectively — is the same energy that flows through the entire universe. In terms of physics, we are all constantly exchanging molecular and subatomic particles. Psychology tells us that we share thoughts and feelings. Physically and spiritually, we are the same in many ways. The fact of our sameness does not erase or minimize the very real differences that divide us. Nonetheless, focusing on our sameness can make our differences less threatening and encourage creativity and cooperation in the search for ways to live together. Multiracial feminism's emphasis on the simultaneity of sameness and difference provides a critique of the binary thinking that is the root of oppressive forces such as racism, classism, sexism, homophobia, ableism, and transphobia. It responds to our human needs for connection with others and with something larger than ourselves. Accepting our shared humanity means not only seeing our connections with others with whom we disagree but also accepting all the parts of ourselves, especially those parts we might like to disavow.

Activists and critics often identify and oppose unjust exercises of power through what some sociologists call "injustice frames." 28 This oppositionality is a valuable form of resistance to oppression 
and generates energy that motivates important social change work. At the same time, Anzaldúa recognizes, oppositionality-in her terms, "counterstance" - "is not a way of life." She sees violence in our opposition, even when it comes from a place of loving ourselves and others whom we view as oppressed. ${ }^{29}$ Anzaldúa, like Lorde, Alexander, Fernandes, and other multiracial feminists, values the counterstance as a critical part of breaking away from ideologies of domination: opposition is a step toward changing our thought patterns and beliefs. ${ }^{30}$ But in occupying one side of a binary, our oppositional stance is stuck in relation to the systems and ideologies we oppose; it limits how we can move and respond.

Some of the activists in my study reflected that an oppositional stance can lead to acting out of anger and judgment rather than compassion. Burmese American feminist activist Sandee Pyne says of her days as a young animal rights activist, "We felt morally righteous, and I think any time you feel morally righteous you need to really beware." After personal conflicts led to Sandee leaving her job with an animal rights organization, she found herself confronting questions of "Who I wanted to be, how do I practice my beliefs? I say I care about stopping suffering, but meanwhile I was doing things that made women fearful. Ruining their fur coats. You don't have to like the people who disagree with you, but you should not dehumanize them." Reflecting on the changes in her life, Sandee describes the break from the organization as an opportunity to rethink her approach to social change and views her earlier ways of expressing her opposition to social injustice as placing her in opposition to other people. As she became more of a practicing Buddhist, she used meditation to help transform her oppositionality into loving kindness and felt a need to change her activist strategies to reflect her desire to act from a place of compassion rather than anger. ${ }^{31}$

While maintaining oppositionality means always fighting and always seeing oneself as separate, focusing on what we share as humans can help us choose different approaches to conflicts. Anzaldúa hopes activists can find a more peaceful way to live. She writes "the answer to the problem between the white race and the colored, between males and females, lies in healing the split that originates in the very foundation of our lives, our culture, our languages, our thoughts." Anzaldúa calls for foundational changes in consciousness 
in order to find peace, asking us to accept "the bad and the ugly" along with the good. ${ }^{32}$ This is a call for psychic and spiritual acceptance - a call to accept our own humanness by starting with the difference, bad and good, within ourselves.

In her oral history, Black queer activist Monique Meadows describes coming to such personal acceptance, along with an understanding of feminism as something that "honors all of who we are." As a young feminist, Monique tried to fit into what she thought was a feminist "look": "just practical, bare-bones. And that is not me at all ... the aesthetic that I like is kind of polished. I like clothes; I like makeup; I like high heels. I really love that stuff actually." Eventually, she came to understand her feminism as being "about women finding our own voices and having the right and the space to express that however we see fit without other people telling us, 'No, you can't do that; you have to be this.' So that essentially we're our own inner authority." Monique's ideas about what a feminist was and feelings about what she should be opened up as she explored her spirituality. As a witch and a practitioner of Yoruba, she says, "I have to believe in my own inner authority and in my own voice. If not, then how am I going to lead a ritual? What would be the point if I don't believe I have the power to do it?" Believing in women's power and authority over their own lives, Monique learned to claim power and authority for herself and accept all of who she is.

Accepting oneself and others means accepting our power and privilege as well as those parts of ourselves that are socially devalued. Anzaldúa emphasizes that oppressor and oppressed are both present within each of us, a theme that is present throughout This Bridge Called My Back and its successor, This Bridge We Call Home. In the latter, feminist scholar Irene Lara reflects on her white ancestors: "Whether I am comfortable with it or not, their genealogies live in my bones as well. Like other people of mixed race before me, I work to make peace with them. Because not to acknowledge and love all who I am is to be defeated, again." ${ }^{3}$ At the same time that the "proudly defiant" counterstance to oppression works to revalue those parts of ourselves that have been devalued by dominant culture, it often devalues people and parts of ourselves that we connect with oppression, perpetuating the violence of dualism. To "make peace with" the oppressor is not to tolerate oppressive behavior, but to recognize 
it as human, as stemming from human experiences and emotions and to recognize that the root of violence is in the concept of separateness, which is something, widely shared, that our spirits work to overcome.

For most of us raised within an oppositional culture, to truly, deeply accept the oppressor within each of us requires working with one's emotions or spiritual energy and slowly changing our habitual responses. Some activists explicitly discuss spiritual practices that help them be more accepting of themselves and others. As a selfdescribed "black female, left-handed, vegetarian, spiritual, kind of womanist individual who lives her life outside of a box," Papaya Mann's spiritual practices have helped her to accept herself and others and to act from a place of love and generosity in her work organizing lesbians and gays of color and developing education and services addressing HIV/AIDS. She says that her spirituality "keeps me centered. Keeps me in a place of love." Papaya describes how her spirituality helps her accept herself and others: "It rejuvenates me. And allows me to ... forgive myself for the things that I can't do or that I'm not interested in doing. Forgive others for the things that they do or sometimes don't do." Papaya's acceptance of herself and others helps her cope with conflicts and "rejuvenates" her even when she has been "burned." Using therapy, recovery programs, spiritual practices, writing, and other creative or personal work, activists in my study work to accept, emotionally as well as intellectually, all the parts of themselves and to extend that acceptance to others.

Acceptance of oneself and others happens also through the difficult work of examining ourselves - our pain and anger as well as our beauty and joy - with honesty and kindness. Lorde describes her vision of the love, patience, and acceptance that result from this collective work: "We will begin to see each other as we dare to begin to see ourselves; we will begin to see ourselves as we begin to see each other, without aggrandizement or dismissal or recriminations, but with patience and understanding for when we do not quite make it, and recognition and appreciation for when we do." ${ }^{34}$ To see ourselves and each other honestly and kindly means believing that we are all okay as we are, while continuing to work to improve ourselves. It depends on a faith that caring for ourselves, as for others, is good and therefore spreads goodness in the world. 
This work, again, involves accepting the oppressor, and the effects of oppression, within. Criticism that is honest but not kind, criticism that judges or rejects our human failures, works differently on the emotions and spirit than loving criticism, in which we are all in it together, working to understand ourselves and each other and figuring out how we can all change for the better. According to Buddhist teacher Chögyam Trungpa, such honest and kind self-examination is the first step in the Shambhala tradition of spiritual warriorship, the essence of which is "refusing to give up on anyone or anything." 35

Feminist critic Heather Love's study Feeling Backward: Loss and the Politics of Queer History exemplifies a critical refusal to give up on any part of our queer past. Love argues that we need a history of injury "to attend to the social, psychic, and corporeal effects of homophobia" because "it is the damaging aspects of the past that tend to stay with us." Viewing the pain in past queer texts honestly, without trying to make it positive to fit a hopeful politics, Love calls for us to remember the past without disavowing its painful experiences. ${ }^{36}$ Such honest examinations of the difficult past and present contribute to our ability to accept our humanity as it is - full of pain, fear, anger, loss, shame, and disappointment, as well as love, hope, faith, and joy. When we are aware of and accept ourselves as we are, we can work on creating the future we hope for.

\section{Accept Our Power}

Self-examination not only helps activists to accept our own humanness and to see our connections with others, it leads to discovering the power we need to change the world. Lorde writes of selfexamination as a crucial part of empowerment, which she defines as "our strengthening in the service of ourselves and each other, in the service of our work and future." ${ }^{37}$ Empowerment is the work of discovering one's erotic power, a power that enables creativity and movement. Erotic power is not a power that can be held or wielded but a power that flows through everything and can be accessed by anyone. ${ }^{38}$ This power adds to our personal strength and ability not just to survive hardship but to use our experiences of pain, anger, fear, and sadness to understand those feelings in others and act with compassion. Discovering our erotic power, we find possibilities for 
creative and political work that we might not have seen before. Then, by doing our work, we share our power with others.

Monique's description of how her spiritual work connects with her activism provides one example of self-empowerment as political work. Monique explains that her spiritual work sustains her, "gives me this sense that that there is order to all of this ... I believe very much that we are all connected." With this understanding of connection, she sees that, "as I do my work and heal my inner world, it heals my whole lineage. Because there's a whole legacy, like for many people, of violence and emotional abuse and poverty and all of that, and I feel that as I do my work, I'm able to change the path for the people that come after me." Monique quotes Williamson: "Playing small doesn't serve the world." ${ }^{39}$ Her understanding of oppression and her belief in connection lead her to develop her own power, so that she can contribute to the world in positive ways. Through examining herself and nurturing her creative powers, she found her own way to serve the world: "My mission is to serve, embrace, and inspire women in their healing."

Loving criticism takes responsibility for the power that each one of us has to change ourselves and the world, rather than trying to place blame. It focuses on what we build rather than on what we can take down. To blame dominant culture and ideologies and/ or privileged people for causing suffering separates the world into those who are responsible and those who are victims - oppressor and oppressed - a violent division that cedes power to people with more privilege and further disempowers those who have less. Blaming does not create change. As Thich Nhat Hanh writes, "Only love and understanding can help people change." 40 Anzaldúa articulates the bind created by blaming others for oppression: "Blocked, immobilized, we can't move forward, can't move backwards. We abnegate." ${ }^{41}$ She points out the choice that we all have to feel empowered or to feel victimized. To say that one can choose to be empowered does not deny the reality of structural oppression and other limits to what one can do in the world. Keating calls this "the paradox of personal agency and structural determinacy" and notes that Anzaldúa writes from within this contradiction, declaring her inability to resolve it. ${ }^{42}$ The choice to feel empowered is expansive, 
the location of creativity, and a source of love. Through loving criticism, we accept responsibility for our role in conflicts and our power to respond, construct, create, and transform. We refuse to circumscribe people as victims and oppressors.

Many activists in my study resist the position of victim, focusing instead on personal power and an understanding of negative experiences as gifts. Reflecting on negative experiences from her life and the lives of Burmese migrants with whom she works in Thailand, Sandee refuses the idea that she is special or that she has been a victim, saying people "might be traumatized. They might be victimized by situations, but they're not just victims." Indeed, she thinks "traumas and pain are potentially catalytic events for creating greater social justice." As Anzaldúa writes, wounds are openings with the potential to create change. ${ }^{43}$

The gratitude Sandee expresses for all she has experienced is a feeling shared by South Asian American queer feminist Sivagami "Shiva" Subbaraman, who claims that her spiritual faith is what enabled her to survive painful experiences: "A lot of people were mean to me and abused me, but a lot of people have also loved me, and if love is God, then I have seen God at work, too." Shiva sees it as a difficult and "painful paradox" that good things often follow tragic or painful events. Reflecting on her mother's death and the sexual abuse Shiva suffered at the hands of her grandfather, she says:

It was very painful for me that [my mother] died when I was twenty-two, but on the other hand it helped me grow and become who I am today ... My life would have been easier if my grandfather hadn't existed. But ... I do believe in that old saying that pain hollows you out, and hopefully if you understand the role of pain, it allows you to hold more.

Accepting the pain and abuse she has suffered, Shiva views those experiences as gifts that enable her to understand more and to change the world for future generations through writing and organizing around domestic violence and child sexual abuse as well as South Asian queer issues. Activists and critics can transform their painful experiences into sources of strength and empowerment. Accepting our power, we can better understand the power that others have to affect the world. 
In her famous question, Lorde claims the power of all of who she is, all of her experiences, and challenges each of us to use hir ${ }^{44}$ own power in service of hir purpose: "Because I am a woman, because I am Black, because I am lesbian, because I am myself-a Black woman warrior poet doing my work - come to ask you, are you doing yours?" 45 Rooting herself in the collective identities that are parts of her, but not all of her, and in her own unique "self," she declares her work as her own. She does not make prescriptions for anyone else but asks if each of us is doing hir work, and encourages each individual to evaluate hir life according to hir own sense of purpose. Lorde's question enacts a kind of critique that helps us to find our own inner sense of value and principles and to determine for ourselves what we contribute. Such a loving kind of critique honors each person's struggle and helps develop a sense of possibility in everyone.

Antiracist feminist scholar Celine Parreñas Shimizu honors the power and dignity of all humans, and Asian American women in particular, in The Hypersexuality of Race: Performing Asian/American Women on Screen and Scene. She shows that, as producers, consumers, and critics of representation, Asian American women find "trauma, terror, and pain as well as joy, self-recognition, and alliance" in hypersexual representations and negotiate their own understandings of themselves and their power through and in relation to hypersexuality. ${ }^{46}$ Like Love, Shimizu resists the reduction of human experience to fit a simplistic politics. She finds in the complexity of Asian American women's representation the beauty of human struggle and imagination. Shimizu finds a way to hold human vulnerability and agency through rigorous criticism that respects human intelligence, creativity, and power while understanding the real impacts of structural oppression.

\section{Face Conflict with Kindness}

Accepting our power enables action for social change, which often involves conflicts, large and small. Maintaining focus on our shared humanity enables us to practice kindness as a strategy for deep, lasting change. Papaya hopes that we can all learn to handle conflicts without anger or hostility, "because clearly on a small level it's conflict between individuals. But on a large level it's the same 
conflict that creates conflict between us as people, as cultures, as races, as gender[s]." Like Anzaldúa, Papaya views all conflicts as having the same root and believes we need to transform our feelings of hostility into a positive force. If we understand all conflicts as connected and rooted in feelings and beliefs that we are separate, then each conflict is an opportunity to transform the larger problem of separation. Each interaction becomes an opportunity to practice peace and being kind with each other-something that is difficult and necessary because the oppression we live with relies on separation, fear, suspicion, and hostility. Even, or especially, when working for positive social change - actions rooted in love for others and belief in human dignity - it is easy to get swept up in conflicts, focusing more on being right than on being kind.

Because the day-to-day work of social change entails a lot of conflict, the ideals behind the work can get lost. Spiritual teacher Ram Dass and faith-based activist Paul Gorman comment on the challenge of keeping human commonalities in mind on "the battlefield" of political activism. They ask, "What kind of victory is it when someone is left defeated? ... Do we just want to be right, or do we all want to be free?" 47 If what we want is to win, then others are left behindsomeone loses. Freedom, for these authors, means everyone participates - no one feels forced to give anything up. Freedom for everyone requires respecting the dignity of each person. Being correct is not the same as being empowered, or free. People often get stuck, attached to a position, a tactic, or an emotion, when we feel correct. Such fixity can prevent movement and growth, locking one down in a conflict while other possibilities go unnoticed. Calling for empowerment rather than correct politics, Lorde argues that it is more important for people to learn and grow than to create a correct system without them. ${ }^{48}$ Attempting to force people to change their ways of living and thinking, rather than allowing individuals to find their own paths, has led to notorious periods of oppression and violence. This is why Thich Nhat Hanh calls for "openness and nonattachment from views ... [that] creates respect for the freedom of others." ${ }^{49}$ The political work of self-empowerment produces possibilities and increases chances for survival.

Letting go of the attachment to being right can contribute to a sense of empowerment. Monique found that she had to let go of 
her investment in being right in order to speak her truth. As a leader in her professional and spiritual communities, she learned to "speak with conviction and authority" and says, "I feel much more confident in my ability to express my opinions." She realizes that her "ego was very invested in" being right and impressing people. "Over time," she continues, "I've given myself permission to not be right. I don't have to be good, it just has to be real. It just has to be truth." Asked how she knows what is true, Monique replies, "because it feels right to me. It feels in line with my values, with my experience. It feels like it's not coming from a place of fear, rather a place of love." With this statement, she signals the erotic in the sense used by Lorde, the feeling of everything coming together in connection to her deepest self, which lets her know when she's found her truth and gives her the power to speak it. Not needing to be correct or to win, we can tap into our erotic power, find our truths, and speak them, and from this place of empowerment, we can respect each person's need to find hir own truth.

Following the example of Lorde's question, with its respect for each person's potential, loving criticism involves a shift in focus from oppression to possibilities. Some activists find that reminding themselves of their foundational beliefs and principles opens up possibilities for action and change when a focus on injury might shut down connections. Focusing on their values, these activists change their approach to the situation, which changes the situation. Discussing her work as the development director for a national queer youth organization, Monique describes the challenges of working with mostly white male donors. She realizes that she often assumes that white men "are not interested in anything I have to say. That's not helpful for me to believe that. Sometimes it's true. Sometimes it's not true. I'm not always sure that I know." Regardless of whether or not there is racism or sexism at work in these meetings, she realizes that her assumption does not make her feel good or confident. She adds, "I can think it protects me against being harmed in some way, but it doesn't. In fact, it can end up blocking important connections I could make." Even if Monique's diagnosis of racism or sexism is accurate, that truth does not protect her, does not make her feel good, and can prevent her from acting in a way that promotes positive change. 
Monique talks about the need to balance her awareness of race, class, sexuality, gender, and related dynamics with her desire to "move to a different level of understanding of humans," saying, "it's there; it's real. And at the same time, how do I see the higher selves?" Relating a story of a meeting held with a potential donor who was completely ignoring her, directing all of his attention toward the organization's white male executive director, she recalls thinking, "Okay, Monique, you have a choice here. You can assume that he's doing this because you're Black and [the executive director]'s white, or you can assume that he hasn't met you before, so he just doesn't know you. So ... use your social grace to put yourself into this conversation." The strategy was successful, and the man "warmed up" to Monique by the end of the meeting. She admits that it is difficult not to make assumptions about people, particularly when race is involved, but her commitment to treating people with respect and compassion requires such work. She also realizes that making assumptions about where people are coming from, even if they are true, closes down possibilities for connection and movement. By assuming the best about where people want to go, Monique encourages positive change.

Black lesbian feminist Colette Stone ${ }^{50}$ uses a similar narrative structure to describe a different situation in which her belief that "the universe is abundant" helps remind her to act from her best principles. Colette frequently partners with other organizations that compete for the same grant funding as her national organization. Even after she learned that a partner organization was not supporting her by letting grant foundations know that the two groups were collaborating on projects, Colette felt it was important to continue to assist the organization by sharing information about upcoming grant competitions. She explains, "there was a moment where I was like, 'Keep it to yourself.' But I was like, '[Colette], that's ridiculous. If you really believe the universe is abundant and there's enough, then it is enough."' Like Monique, Colette represents these thoughts as a conversation with herself. Both women see two choices, each aligned with one version of herself. Each narrator describes herself as initially reacting from what I call the smaller self, the part of her that acts habitually, responding to negative feelings or seeking immediate pleasures. This smaller self's response is interrupted 
by the voice of the larger self, the one that realizes a deeper connection with the universe or the divine, who advises making a positive choice that follows her spiritual beliefs. ${ }^{51}$ Acting from her best principles, based on her belief in abundance, Colette serves her purpose of bringing more social justice to the world. Focusing on her best principles, each activist and critic can do her part to create possibilities for positive change.

Because oppression does not teach us to be kind or to value ourselves or others from marginalized groups, treating each other with respect requires such conscious practice. Lorde writes of the work required to treat each other kindly: "What was native has been stolen from us, the love of Black women for each other. But we can practice being gentle with ourselves by being gentle with each other. We can practice being gentle with each other by being gentle with that piece of ourselves that is hardest to hold." 52 By connecting the difficulty of being kind and gentle with each other with oppression, Lorde argues for the necessity of tenderness in social justice work. Using the word "practice," she claims that acting with kindness is itself a way to learn to act with kindness. That is, individual acts of kindness are a form of practice that help to make a habit of kindness, and treating one person with kindness helps one learn to treat others with kindness.

Drawing on a Buddhist concept of practice and view of the big picture and of each moment as "interconnected," Sandee sees each interaction as an opportunity to practice peace. She describes the focus on each moment as Buddhist because "you are trying to be aware, ... mindful of how you speak, mindful of the fact that every action has a reaction, a consequence." Her practice includes being aware of her thoughts and trying to stay in the moment. She connects mindfulness with being present with another person, trying to accept the other person without the screen of thoughts, which include past experiences and ideas that can obscure understanding of the present moment. Her practice, she says, is "to be right here and look at you and really try and see you." Sandee combines Buddhist mindfulness practice with structural critique, so that part of one's awareness of a situation is of privileges, options, experiences of victimization, and limits that have a basis in political, economic, and social structures. ${ }^{53}$ Through the practice of observing 
and letting go of thoughts that lead to separation and judgment, one can better understand larger and smaller forces that shape people's lives and individual moments.

Alexander describes the possibilities for this kind of critical and compassionate consciousness: "We can continue holding on to a consciousness of our different locations, our understanding of the simultaneous ways dominance shapes our lives and, at the same time, water the erotic as that place of our Divine connection which can transform the ways we relate to one another." 54 Connecting with the erotic energy that flows through each of us, we can find the power to create more peace. As Alexander emphasizes, this does not entail forgetting the real effects of oppression but seeing possibilities for transformation. Artist and educator Renée M. Martínez describes the shift from focusing on oppression to focusing on possibilities as a move from warrior to peacemaker. Martínez's approach to activism changed as she discovered prejudice in people who were close to her. As she was able to see friends and family members as people who perpetuate injustice and who still deserve dignity and love, she was also able to see others as whole people. Another way of being in the world, peacemaking preserves human dignity by treating people with honesty, kindness, and respect for their power. ${ }^{55}$

Peacemaking is defined by the centrality of its principles and its faith in possibility. No longer stuck in feelings of hurt and unfocused anger, Martínez is free to seek other ways to work for justice while respecting human dignity. She describes this peaceful approach as strong, powerful, and faithful, and describes working with those who could be dismissed as oppressors as an act of bravery. Believing in the possibility of peace, Martínez finds connections where before she might have focused on conflicts. Turning gaps into bridges has been a major contribution of multiracial feminism - a contribution emphasized in alternate terms for this form of consciousness, such as interstitial feminism and intersectionality. From the spaces between movements and theories focused on gender, race, class, sexuality, disability, and nation separately, multiracial feminists have created broadly inclusive theories and politics from their belief that, as the World Social Forum activists put it, "another world is possible." 
The changes Martínez describes may be subtle: letting go of the habit of categorizing people as friend or foe; focusing on principles, such as her belief in human dignity, rather than on conflicts; resisting the tendency to judge; looking for commonalities. Yet she describes the effects of these shifts on her life as "revolutionary." ${ }^{56}$ Similarly, Sandee calls peacemaking "action-oriented" and "infinitely radical." Reflecting on the movement for democracy in Burma, she explains, "I'd love to see wholesale change. But there isn't wholesale change if I'm not behaving democratically, even if [that] means allowing space for people I don't agree with and I find really objectionable." For Sandee, like Dass and Gorman, the victory of regime change is not better than the freedom of universal dignity. The belief that meaningful change is only possible if we respect human dignity is at the core of peacemaking. Acting from this principle is a subtle way to create deep change.

The principles and beliefs of peacemaking connect single peaceful acts with global movements. Martínez views peace efforts as encouraging hope:

Our answers somehow lie in building and creating, moving forward and beyond, allowing wounds to heal and scars to fade gracefully. Not to forget or deny pain, but to embrace it and move on. We must believe that atrocities and injustices will not prevent us from flying, or even from soaring ... I'm tired of seeing energy drained into a dark pit of despair, rather than amplified by hope. ${ }^{57}$

The "somehow" in this quote points to the difficulty of explaining peacemaking in words, the impossibility of pinning down emotional and spiritual effects with words. This sense of not knowing exactly how these things happen permeates discussions of the spiritual aspects of activism, along with an acknowledgement of the difficulty - and necessity - of the work. Somehow, we find creative ways to move, build, and connect. Hope grows; healing happens, and we find more energy to continue the work. ${ }^{58}$

\section{Nourish Ourselves through Positive Action}

Sustaining the practice of peacemaking requires practicing kindness with ourselves as well. Because "too much suffering can destroy our 
capacity to love," Thich Nhat Hanh teaches that we need "to stay in touch with things that are dreadful in life and also things that are wonderful." ${ }^{59}$ Sedgwick also writes of the importance of focusing on the positive as a way to care for oneself. She views both the paranoid and reparative positions as equivalent in their capacity for producing knowledge. She argues, though, that the paranoid approach to criticism can block positive feelings, while the reparative position is pleasure-seeking. ${ }^{60}$ Seeking to discover ways that individuals and communities survive and nourish themselves, often in a culture that does not support them, the reparative critic nourishes hirself.

Native Canadian educator Kim Anderson's project A Recognition of Being: Reconstructing Native Womanhood is a reparative one. She examines how Native women "maintain their power, in spite of all the oppression" and finds the answer in a four-part process through which Native women define themselves by "resisting negative definitions of being; reclaiming Aboriginal tradition; constructing a positive identity by translating tradition into the contemporary context; and acting on that identity in a way that nourishes the overall wellbeing of our communities." She states that her focus in the book reflects her purpose of contributing to the health and empowerment of Native women. ${ }^{61}$ This loving project carries Anderson's hope for dialogue, vision, and reflection that will help Native women and others create more balanced, healthy, and respectful lives.

Reparative criticism is a kind of positive, or hopeful, thinking that, Sedgwick notes, sometimes comes from "the most paranoid-tending people." ${ }^{62}$ For Shiva, reparative practice is a response to a paranoid worldview. "You have to make the world safer or you're just there, feeling afraid." Reflecting on her early experiences of violence, she notes "For me the world was not safe ... I was clearly not protected." While she supposes her abusive grandfather "had malicious intent," she goes on to say that he was the only family member of whom she could say that clearly. For others, "it was ignorance, innocence, stupidity, denial, all those human culpabilities." Because she does not view the world as malicious, Shiva finds possibilities to make positive change in mainstream communities such as the local Hindu temple and progressive South Asian communities. Her belief in good intent supports her work to make the world safer than it was for her. Her beliefs and activism provide nourishment in 
a world that has not supported her. Positive thinking and action can be a healing response to a paranoid world view.

hooks prescribes such hopeful thinking to counter the stress that comes with Black women's paranoia: "Since so much of our personal worrying has to do with feeling that the worse that can happen will, we can truly counter this negative by changing thought patterns." She relates the many health problems that make stress life-threatening for Black women and notes that "stress does not empower us to handle whatever comes our way." She attributes the paranoid perspective in Black women to a fear of disappointment; this analysis echoes, in some ways, Sedgwick's view that the paranoid critic fears being surprised by bad news. hooks identifies in the paranoid position a stifling of negative emotions. Letting go of her attachment to "being tough," she appreciates the care that she is able to receive when she expresses negative feelings. By letting go of fears of appearing weak or having bad surprises, hopeful thinking and action open space for caring to happen.

In addition to relieving individual stress, love and positive thinking also sustain struggles for justice. hooks writes, "what would it mean for black people to collectively believe that despite racism and other forces of domination we can find everything that we need to live well in the universe, including the strength to engage in the kind of political resistance that can transform domination?" ${ }^{3}$ Her rhetorical question here reframes the focus on kindness taught by the 17th Karmapa in a way that makes clear the political impact of the teaching. A shift in perspective from a focus on how oppressed people have suffered to how the universe supports our survival can provide the faith and love needed for transformation. White queer pagan activist Eric Eldritch describes the belief in one's own individual and collective power as "magic": "Magic is the hope and the belief in transformation and your ability to make it happen." The belief that one can find what one needs in one's self and community makes it so. As we trust in our own resources and nourish ourselves by focusing on love and possibilities, we find ways to survive and energy to change the world. 


\section{Conclusion}

In Sandoval's work, love is inseparable from differential consciousness. She writes, "it is love that can access and guide our theoretical and political "movidas." Love leads us to social action and guides our methods. Indeed, for Sandoval, social action is a "mode of 'love' in the postmodern world." In her descriptions of the way love works on us, and of differential consciousness as "soul," one can glimpse the spiritual understanding that guides her Methodology of the Oppressed. Her description of differential consciousness as an "internally controlling yet unruly power" that works in and through those who struggle for liberation and justice resonates with Lorde's notion of erotic power and what Anzaldúa terms "spirit." Sandoval's work on differential consciousness is also helpful for thinking about how a worldview and way of thinking can be found in different places with tentative, or even no, historical connections. Identifying some textual manifestations of differential consciousness in a range of theoretical work, her study develops appreciation for liberatory work that crosses a range of different identities, movements, organizations, priorities, and tactics. In the traces of differential consciousness I recorded through oral history and studied in print, I found a spiritual approach that can guide social action: loving criticism. ${ }^{64}$

Loving criticism seeks knowledge that does something beside expose the truth of oppression. It seeks to amplify kindness, creativity, love, and joy wherever it can find it, so that the critic and the world can draw on these resources. Critique serves an important function because of the centrality of consciousness to oppression. Yet it easily becomes stance and counterstance, positioning, reacting, paranoia. Too often, we make accusations (of racism, sexism, homophobia, classism, etc.), which some respond to as a challenge and most respond to with defensiveness, because we have dehumanized the racist, sexist, classist, and homophobe within each of us. Through loving criticism, we look for and encourage the best in others and ourselves, trusting that nourishing our creative parts is intrinsically good.

Spiritual work is difficult. It refuses us the security of thinking we know anything, including who we are and who or what is good or bad. It challenges us to the core and refuses to let us paint anyone as enemy, even those who commit evil, destructive acts, 
even ourselves. It has implications for how we live every moment of our lives, from how we eat breakfast, to what we teach our children, to what jobs we do, to how we engage in conflicts with our families, neighbors, coworkers, and political representatives. And it reminds us that all these things are practice, which means we will continue to get it wrong, and that we should not take ourselves, or spirituality, so seriously.

The truths that come from experiencing our connectedness can help us work across differences, practice love in our personal and political lives, and cultivate differential consciousness. Love leads us to bring old knowledges into our work and to find common ground with those whom we protest and criticize. Focusing on love helps us produce knowledge that nourishes people who suffer and encourages understanding and compassion. Love helps us find alternatives to oppositional thinking and violence so that we can create deep, lasting change.

\section{Notes}

This article was inspired by Thich Nhat Hanh's audio CD Touching the Earth (Sounds True, 2005). Thanks to Michelle Corbin, Vicki Watts, Leila Rupp, and Feminist Studies reviewers for feedback on earlier versions of this essay.

1. Becky Thompson, "Multiracial Feminism: Recasting the Chronology of Second Wave Feminism," Feminist Studies 28 (Summer 2002): 337. The philosophy of looking at "interlocking" oppressions has also been called "intersectionality," in Kimberlé Crenshaw, "Mapping the Margins," Stanford Law Review 43 (July 1991): 1241-99; "interstitial feminism," based on Hortense Spillers, "Interstices," in Pleasure and Danger: Exploring Female Sexuality, ed. Carol S. Vance, (Boston: Routledge and Kegan Paul, 1984), 73-100; and "US third world feminism," in Chela Sandoval, Methodology of the Oppressed (Minneapolis: University of Minnesota Press, 2000).

2. Koichi Tohei, Ki in Daily Life, complete revised ed. (Tochigi, Japan: Ki No Kenkyukai, 2001), 75.

3. Gloria Anzaldúa, Borderlands/La Frontera (San Francisco: Aunt Lute, 1987); Gloria Anzaldúa and Cherríe Moraga, This Bridge Called My Back: Writings by Radical Women of Color (New York: Kitchen Table, 1983); Gloria Anzaldúa and AnaLouise Keating, This Bridge We Call Home: Radical Visions for Transformation (New York: Routledge, 2002); Audre Lorde, Sister Outsider (Berkeley: The Crossing Press, 1984; New York: Quality Paperback Book Club, 1993 
[Citations are from the Quality Paperback Book Club edition.]); Mab Segrest, Born to Belonging (New Brunswick, NJ: Rutgers University Press, 2002); Alice Walker, The Color Purple (New York: Harcourt, 1982), In Search of Our Mother's Gardens (San Diego: Harcourt, 1983), and We Are the Ones We Have Been Waiting For (New York: New Press, 2007); Akasha Gloria Hull, Soul Talk (Rochester, VT: Inner Traditions, 2001); Cherríe Moraga, Loving in the War Years, expanded ed. (Cambridge, MA: South End, 2000); bell hooks, Sisters of the Yam (Boston, MA: South End, 1993); Sandoval, Methodology of the Oppressed; Paula Gunn Allen, The Sacred Hoop (Boston, MA: Beacon, 1992) and Grandmothers of the Light (Boston, MA: Beacon, 1991); M. Jacqui Alexander, Pedagogies of Crossing (Durham, NC: Duke University Press, 2005); Leela Fernandes, Transforming Feminist Practice (San Francisco: Aunt Lute, 2003).

4. Luisah Teish, Jambalaya (San Francisco: Harper and Row, 1985); Starhawk, Dreaming the Dark (Boston, MA: Beacon, 1982); Charlene Spretnak, The Politics of Women's Spirituality (Garden City, NY: Anchor, 1982); Carol Christ, Laughter of Aphrodite (San Francisco: HarperCollins, 1988); Mary E. Hunt, Fierce Tenderness (New York: HarperCollins, 1989); Katie Cannon, Black Womanist Ethics (Atlanta, GA: American Academy of Religion, 1988); Judith Plaskow, Standing Again at Sinai (New York: HarperCollins, 1990); Rita Gross, Buddhism After Patriarchy (Albany: State University of New York Press, 1992); Delores Williams, Sisters in the Wilderness (Maryknoll, NY: Orbis, 1993); Ada María Isasi-Díaz, Mujerista Theology (Maryknoll, NY: Orbis, 1996).

5. See Rosemary Radford Ruether, Feminist Theologies: Legacy and Prospect (Minneapolis: Fortress Press, 2007); Marcia Y. Rigga, “'A Clarion Call to Awake! Arise! Act!': The Response of the Black Women's Club Movement to Institutionalized Moral Evil," in A Troubling in My Soul:Womanist Perspectives on Evil and Suffering, ed. Emilie Townes (Maryknoll, NY: Orbis, 1993); and Carla L. Peterson, "Doers of the Word": African-American Women Speakers and Writers in the North 1830-1880 (New Brunswick, NJ: Rutgers, 1998).

6. This philosophy is expressed most clearly in US Third World feminist literature by María Lugones, "Playfulness, 'World'-Travelling, and Loving Perception," Hypatia 2, no. 2 (Summer 1987): 3-19.

7. I eventually expanded the pool to include one person who identifies as neither queer nor straight. One of the edited interviews was published as "'My Story is Really Not Mine': An Interview with Latina Trans Activist Ruby Bracamonte," in Feminist Studies 37, no. 2 (Summer 2011): 441-467. For further analysis of the interviews and for participant biographies, see Sharon Doetsch-Kidder, Social Change and Intersectional Activism: The Spirit of Social Movement (New York: Palgrave Macmillan, 2012).

8. I find the term "oppression" useful for the way it can evoke a kind of common sense understanding that prejudice, discrimination, and socioeconomic and political forces have acted historically to limit the political and economic power of people in certain groups or who share cer- 
tain (socially constructed) identities. I do not mean that there is any simple division of people or groups who are "oppressed" or "not oppressed."

9. See Segrest, Born to Belonging; Eve Kosofsky Sedgwick, Touching Feeling: Affect, Pedagogy, Performativity (Durham, NC: Duke University Press, 2003); hooks, Sisters; and numerous contributions by hooks and Walker to US Buddhist magazine Shambhala Sun, www.shambhalasun.com.

10. Sandoval, Methodology of the Oppressed, 57. "Oppositional consciousness" refers to thoughts, feelings, and tactics that resist neocolonization and other forms of domination. Oppositional consciousness can take many forms in response to different structures and exercises of power and seeks to equalize power relations between individuals and groups.

11. Ibid., 58.

12. Ibid.

13. Ibid., 197 n. 61.

14. Marianne Williamson, Healing the Soul of America: Reclaiming Our Voices as Spiritual Citizens (New York: Touchstone, 2000), 43.

15. Sedgwick, Touching Feeling, 143, 149.

16. María C. Lugones with Pat Alake Rosezelle, "Sisterhood and Friendship as Feminist Models," in Feminism and Community, ed. Penny A. Weiss and Marilyn Friedman (Philadelphia, PA: Temple University Press, 1995), 135-45.

17. See, for example, Lisa Albrecht and Rose M. Brewer, Bridges of Power: Women's Multicultural Alliances (Philadelphia, PA: New Society Publishers, 1990).

18. M. Jacqui Alexander, Lisa Albrecht, Sharon Day, and Mab Segrest, Sing, Whisper, Shout, Pray! Feminist Visions for a Just World (San Fransisco: EdgeWork, 2003).

19. hooks, Sisters, 82.

20. David Edward Shaner, The Bodymind Experience in Japanese Buddhism (Albany: State University of New York Press, 1985), 45.

21. Lorde, Sister Outsider, 56.

22. hooks, Sisters, 82 .

23. I use first names to distinguish my interviewees from authors of previously published work.

24. Elizabeth Gail Currans, "Performing Gender, Enacting Community: Women, Whiteness, and Belief in Contemporary Public Demonstrations" (PhD diss., University of California, Santa Barbara, 2007), 143.

25. Interview by Melvin McLeod, "Kindness Is the Most Important Thing," Shambhala Sun (September 2008): 106. Thich Nhat Hanh calls this interconnectedness our "interbeing dependent co-arising nature," in his Interbeing: Fourteen Guidelines for Engaged Buddhism (Berkeley, CA: Parallax, 1987), 24.

26. Cynthia Dillard, "When the Ground is Black, the Ground is Fertile: Exploring Endarkened Feminist Epistemology and Healing Methodologies of 
the Spirit," in Handbook of Critical and Indigenous Methodologies, ed. Norman K. Denzin, Yvonna S. Lincoln, and Linda Tuhiwai Smith (Thousand Oaks, CA: SAGE, 2008), 289.

27. AnaLouise Keating, “I'm a Citizen of the Universe': Gloria Anzaldúa's Spiritual Activism as Catalyst for Social Change,” Feminist Studies 34 (Spring/ Summer 2008): 63.

28. William A. Gamson, Talking Politics (Cambridge: Cambridge University Press, 1992).

29. Anzaldúa, Borderlands, 78.

30. Lorde, Sister Outsider, 170; Alexander, Pedagogies, 99; Fernandes, Transforming, 27.

31. Personal communication.

32. Anzaldúa, Borderlands, 79-80.

33. Irene Lara, "Healing Sueños for Academia," in Anzaldúa and Keating, This Bridge We Call Home, 434.

34. Lorde, Sister Outsider, 173.

35. Chögyam Trungpa, Shambhala: The Sacred Path of the Warrior (Boston, MA: Shambhala, 1984), 33.

36. Heather Love, Feeling Backward: Loss and the Politics of Queer History (Cambridge, MA: Harvard University Press, 2007), 1-2, 4.

37. Lorde, Sister Outsider, 174.

38. This is similar to the concept of "ki" as described by Tohei in Ki in Daily Life.

39. Marianne Williamson, A Return to Love: Reflections on the Principles of "A Course in Miracles" (New York: HarperCollins, 1992), 190-91.

40. Thich Nhat Hanh, Interbeing, 31.

41. Anzaldúa, Borderlands, 21.

42. Keating, "I'm a Citizen," 59.

43. Anzaldúa and Keating, This Bridge We Call Home, 572.

44. I use the gender neutral zie/hir when a singular, nonspecific pronoun is grammatically required.

45. Lorde, Sister Outsider, 42.

46. Celine Parreñas Shimizu, The Hypersexuality of Race: Performing Asian/American Women on Screen and Scene (Durham, NC: Duke University Press, 2007), 23.

47. Ram Dass and Paul Gorman, How Can I Help?: Stories and Reflections on Service (New York: Knopf, 2003), 156, 175 (italics in original).

48. Lorde, Sister Outsider, 170.

49. Thich Nhat Hanh, Interbeing, 25.

50. Pseudonym. 
51. These terms come from Tohei, who borrows from Zen Buddhist teachings, explaining that one "refers to oneself as shoga, or the smaller self, and to our basic essence as taiga, or the greater self. Zen also teaches us that to discard shoga is to give birth to taiga. This is the same as admonishing us not to be a slave to our smaller selves but to open our eyes to the basic essence that is one with the universal.” Tohei, Ki in Daily Life, 73.

52. Lorde, Sister Outsider, 175.

53. While Sandee distinguishes structural critique from Buddhism, it is consistent with Buddhist practice, particularly with forms of socially engaged Buddhism. See for example, Thich Nhat Hanh, Interbeing.

54. M. Jacqui Alexander, "Remembering This Bridge, Remembering Ourselves: Yearning, Memory, and Desire," in Anzaldúa and Keating, This Bridge We Call Home, 100.

55. Renée M. Martínez, "Del puente al arco iris: transformando de guerrera a mujer de la paz-From Bridge to Rainbow: Transforming from Warrior to Woman of Peace," in Anzaldúa and Keating, This Bridge We Call Home, 48.

56. Ibid., 49.

57. Ibid., 50 .

58. For more on peacemaking, see Ira Chernus, American Nonviolence: The History of an Idea (Maryknoll, NY: Orbis, 2004).

59. Thich Nhat Hanh, Interbeing, 27.

60. Sedgwick, Touching Feeling, 150-1, 136-7.

61. Kim Anderson, A Recognition of Being: Reconstructing Native Womanhood (Toronto: Sumach, 2000), 14-15.

62. Sedgwick, Touching Feeling, 150.

63. hooks, Sisters, 54 and 62-64.

64. Sandoval, Methodology of the Oppressed, 141, 143, 147-48; Anzaldúa, "now let us shift ... the path of conocimiento ... inner work, public acts," in Anzaldúa and Keating, This Bridge We Call Home, 558. 